\title{
Composition of physiological bacterial groups in thermal groundwaters of the Kuldur deposit (Amur oblast, Russian Far East)
}

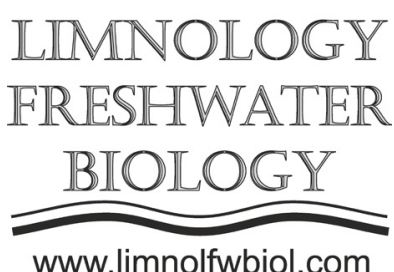

www.limnolfwbiol.com

\author{
Lebedeva E.G. ${ }^{1 *}$, Kharitonova N.A. ${ }^{2}$ \\ ${ }^{1}$ Far Eastern Geological Institute, Far Eastern Branch of Russian Academy of Science, prospect 100 years of Vladivostok 159, \\ Vladivostok, 690022, Russia \\ ${ }^{2}$ Lomonosov Moscow State University, Lenin Hills 1, Moscow, 119991, Russia
}

\begin{abstract}
The research was focused on the distribution, composition, structure, numbers and diversity of predominant bacteria of different ecologo-trophic groups in the thermal groundwaters of the Kuldur deposit (Amur Oblast, the Russian Far East). The research results showed uneven distribution of bacteria of different physiological groups in the groundwaters as well as their low numbers. Thionic and iron-oxidizing bacteria predominated in all studied drill holes. Ammonium and nitrite-oxidizing bacteria were also numerous while Bacillus sp., Paenibacillus sp., Brevibacillus sp. were prevalent in the separated pure cultures
\end{abstract}

Keywords: Kuldur, thermal waters, bacteria, physiological groups, numbers

\section{Introduction}

The Kuldur deposit of thermal waters is situated in the intracontinental southern part of the Russian Far East, near the settlement of Kuldur of the Jewish Autonomous Region. The Kuldur Springs crop out in the central part of Pionersky granite massif and are confined to the meridional fault at the intersection with feathering diastrophism of the north-east direction. Paleozoic granites and granodiorites are the enclosing rocks. Water temperature goes up to $73^{\circ} \mathrm{C}$ (Kompanichenko and Poturai, 2015). Favorable balneological properties allow using these thermal waters for therapeutic purposes in the resorts "Kuldur", "Voenny", "Sanus" and "Gornyak" that are situated in that area.

According to V.I. Vernadsky, water takes a special place among the chemical compounds of the Earth and natural groundwaters are complex dynamic systems that are closely interconnected with the surrounding environment (Vernadsky, 1965). The content and activity of microorganisms in groundwater has a significant influence on its geochemical parameters. The thermophiles that populate hightemperature environments play an important role in biogeochemical processes in ground biotopes. They transform subsurface rocks and gasohydrothermal chemical compounds by synthesizing organic matter and changing the composition of minerals that contain sulfur, iron, silicone and other chemical elements.
Activity of various functional groups of bacteria results in a rapid decrease in the migration intensity of some elements and leads to formation of minerals (Franke and Bazylinski, 2003; Romanenko and Karnachuk, 2004). Study of microorganisms in thermal habitats provides a better understanding of the origin and evolution of the early life and gives an opportunity to evaluate the patterns of their biogeochemical processes.

As the bacterial communities of the mineral waters in this region have not been numerous or sufficiently comprehensive (Fisher and Kompanichenko, 2007; Kalitina et al., 2017a; Lebedeva and Kharitonova, 2019) our research was aimed at studying the distribution, composition and numbers of different physiological bacterial groups in the thermal groundwaters of the Kuldur deposit.

\section{Materials and methods}

The objects of our research included thermal groundwaters of the Kuldur deposit drill holes No.187, No. 2-87, No. 3-87, No. 3-51, and No. 5-51. The highest-temperature waters $\left(71-73^{\circ} \mathrm{C}\right)$ are accessed by drill holes 1-87 and 2-87 at the Kuldur River bend. Drill holes 1-87 and 2-87 have both the highest temperature and the highest output that allows considering this part of the deposit its central zone that coincides with the area of maximum unloading of thermal springs. Drill holes 3-87 and 3-51 on the surface are situated only 2030 meters away from the central drill holes and are also

*Corresponding author.

E-mail address: microbiol@mail.ru (Lebedeva E.G.)

(C) Author(s) 2020. This work is distributed under the Creative Commons Attribution 4.0 License. 
included into the water crushing zone; however, the water temperature $\left(55-60^{\circ} \mathrm{C}\right)$ and the output are much lower there. On the flanks there are drill holes 5-51 with water temperature range of $23-28^{\circ} \mathrm{C}$. The water from drill holes No. 3-87, 3-51 and 5-51 is not used by the resorts because of its lower temperature. Only monitoring observations are performed at these closed drill holes with no water extraction; therefore their hydrodynamic pattern is quite stagnant. Nowadays, all drill holes at the Kuldur thermal field are suspended except for the five of them (1-87, 2-87, 3-87, 3-51, 5-51) (Poturai, 2013).

Thermal water samples were collected into sterile $1000 \mathrm{ml}$. tubes in triplicate in August, 2015. Prior to the analysis, all samples were stored in the refrigerator at $4^{0} \mathrm{C}$ for less than 24 hours. Traditional methods of practical microbiology were applied for revealing and cultivating the bacteria (Lysak et al., 2015). The quantity of different ecologo-trophic groups of bacteria was determined by the method of limiting dilution and the Koch's method (Egorov, 1995). Microorganisms were separated from groundwater with the method of membrane filtration through cellulose nitrate membrane filters with pore size of $0.22 \mu \mathrm{m}$ and $47 \mathrm{~mm}$ in diameter. Saprophytic bacteria were cultivated on organic-enriched agar (OA) and OA 1:10. Other physiological bacterial groups were identified in special selective media (Kuznetsov and Dubinina, 1989). Anaerobic bacteria of different physiological groups were cultivated in an aerostat using GasPak EZ gas generating sachets. Bacteria were cultivated in a thermostat at temperature $25^{\circ} \mathrm{C}$ (drill holes 5-51) and $60^{\circ} \mathrm{C}$ (drill holes 1-87, 2-87, 3-87, 3-51) within 14 days. Bacteria were identified with molecular-genetic methods.

\section{Results and discussion}

The Kuldur thermal spring is situated within the Khingan hydrogeological massif in the AmurOkhotsk hydrogeological fold area. Water is recharged by infiltration of atmospheric precipitation and water inflows from the adjacent elevations; the drainage of water occurs through the local hydrographic network and the springs on valley slopes. Earlier surveys show that the Kuldur thermal waters are characterized by high temperatures (up to $73^{\circ} \mathrm{C}$ ), low mineralization $(<1 \mathrm{~g} / 1), \mathrm{pH}$ over 9 and the following chemical composition: $\mathrm{HCO}_{3}\left(\mathrm{CO}_{3}\right)-\mathrm{Na}$ and $\mathrm{SO}_{4}-\mathrm{Na}$. The waters are substantially enriched in fluorine (up to $27 \mathrm{mg} / \mathrm{l}$ ), silicone (up to $100 \mathrm{mg} / \mathrm{H} \mathrm{H}_{2} \mathrm{SiO}_{3}$ and over), aluminum (up to $10 \mathrm{mg} / \mathrm{l}$ and over), wolfram, molybdenum and some other anionogenic elements. The content of carbon total organic is insignificant and varies between $0.3-3.7 \mathrm{mg} / \mathrm{dm}^{3}$. Thermal water is colorless, bluish, and completely transparent with a slight smell of hydrogen sulfide. The total mineralization of water is $0.30-0.36$ $\mathrm{g} / 1$, alkaline reaction $(\mathrm{pH}-9.4-9.7)$, radioactivity 1.2 2.4 Mache units. Both dissolved and spontaneous gases of thermal groundwaters of these drill holes mostly include nitrogen (up to $98 \%$ ) with admixed inert gases
(Ar, $\mathrm{Kr}, \mathrm{Xe}, \mathrm{He}$ and $\mathrm{Ne}$ ). Admixes pf other gases $\left(\mathrm{CO}_{2}\right.$, $\mathrm{H}_{2} \mathrm{~S}, \mathrm{O}_{2}$ ) are, as a rule, insignificant (Poturai, 2013; Lyamina et al., 2019).

The results of microbiological analysis have shown that, in general, the groundwaters of the drill holes under study contain low numbers of cultivated physiological bacterial groups that, on average, comprised $0.2 \times 10^{2}(1-87)-5.6 \times 10^{3} \mathrm{c} / \mathrm{ml}(5-51)$. Similarly low numbers of bacteria were earlier found by us in different geochemical types of groundwaters in the Russian Far East (Kalitina et al., 2017b; Kalitina et al., 2018; Lebedeva et al., 2019). The lowest composition of ecologo-trophic bacterial groups and their low quantity were found in higher-temperature groundwaters of central drill holes No.1-87 and No. 2-87 (Table) that corresponded to the minimum values of carbon total organic in those waters (Kompanichenko and Poturai, 2015). Aerobic and anaerobic saprophyte bacteria were not discovered in $100 \mathrm{ml}$ water samples from groundwaters of drill holes No.1-87 and No.2-87. The lowest quantity of physiological groups was found in the water of drill hole No.1-87: only thionic bacteria were discovered there $\left(2.8 \times 10^{2} \mathrm{c} / \mathrm{ml}\right)$ thus showing the prevailing bacteria-induced oxidation of reduced sulfur compounds. In addition to thionic bacteria, a small amount of nitrite-oxidizing and anaerobic iron-reducing microorganisms were also discovered in drill holes No.287 (Table). Groundwaters of drill holes No.3-87, No.351 and No.5-51 were characterized with development of greater quantity of different physiological bacterial groups (10-12 out of 16) (Table); it can be attributed to the lower temperature of thermal waters $\left(28-61^{\circ} \mathrm{C}\right)$ that is more favorable for bacterial activity. These waters also have a more stagnant hydrochemical water pattern that probably contributed to formation of specific microbiocenoses. The thermal waters of drill holes No.3-87, No.3-51, and No.5-51 showed prevalence of thionic and anaerobic iron-reducing bacteria, that corresponds to the previously obtained data (Kalitina et al., 2017a) and shows that microorganism-induced oxidation of reduced sulfur compounds and reduction of iron oxides are prevalent in the groundwaters. The quantity of predominant bacterial groups was lower in low-temperature waters (drill holes 5-51) whereas the quantity of ammonia-oxidizing and saprophyte anaerobic microorganism was the highest (Table) thus showing the processes of organic matter decomposition and oxidation of ammonia compounds. Predominant bacteria were separated from the thermal waters and identified. It was established that bacteria Bacillus sp., Paenibacillus sp., Brevibacillus sp. were significantly prevalent in the groundwaters of the drill holes under study.

\section{Conclusions}

Thus, the research shows that thermal groundwaters of the Kuldur drill holes are characterized with uneven distribution and low numbers of physiological bacterial groups. The hottest waters contained the lowest numbers and quantity 
Table. Distribution of dominant physiological groups of bacteria in the underground waters of the Kuldur deposit

\begin{tabular}{|c|c|c|c|c|c|c|}
\hline \multirow{2}{*}{\multicolumn{2}{|c|}{$\begin{array}{c}\text { Dominant physiological groups of bac- } \\
\text { teria }(\text { cells } / \mathrm{ml}): \\
1-87\left(72^{\circ} \mathrm{C}\right)\end{array}$}} & \multicolumn{5}{|c|}{ Groundwater Wells: } \\
\hline & & $1-87\left(72^{\circ} \mathrm{C}\right)$ & $2-87\left(72^{\circ} \mathrm{C}\right)$ & $3-87\left(61^{\circ} \mathrm{C}\right)$ & $3-51\left(60^{\circ} \mathrm{C}\right)$ & $5-51\left(28^{\circ} \mathrm{C}\right)$ \\
\hline \multirow[t]{2}{*}{ Saprophytes } & aerobes & 0 & 0 & 0 & 0 & 0 \\
\hline & anaerobes & 0 & 0 & $0.3 \times 10^{1}$ & $0.5 \times 10^{1}$ & $6.5 \times 10^{1}$ \\
\hline \multicolumn{2}{|c|}{ Thionic } & $2.8 \times 10^{2}$ & $4.3 \times 10^{2}$ & $3.3 \times 10^{3}$ & $2.4 \times 10^{2}$ & $5.6 \times 10^{3}$ \\
\hline \multicolumn{2}{|c|}{ Sulfate Reducing } & 0 & 0 & 0 & $0.7 \times 10^{2}$ & 0 \\
\hline \multicolumn{2}{|c|}{ Ammonium oxidizing } & 0 & 0 & $1.4 \times 10^{1}$ & $0.5 \times 10^{2}$ & $3.2 \times 10^{2}$ \\
\hline \multicolumn{2}{|c|}{ Nitrite oxidizing } & 0 & $0.5 \times 10^{2}$ & $0.7 \times 10^{1}$ & 0 & $0.5 \times 10^{2}$ \\
\hline \multicolumn{2}{|c|}{ Iron oxidizing autotrophs } & 0 & 0 & 0 & $1.0 \times 10^{2}$ & 0 \\
\hline \multicolumn{2}{|c|}{ Iron reducing } & 0 & $1.2 \times 10^{2}$ & $5.1 \times 10^{2}$ & $1.9 \times 10^{2}$ & $2.8 \times 10^{2}$ \\
\hline \multicolumn{2}{|c|}{$\begin{array}{l}\text { The number of developing physiologi- } \\
\text { cal groups of } 16 \text { : }\end{array}$} & 1 & 3 & 11 & 12 & 10 \\
\hline \multicolumn{2}{|c|}{ Average number } & $0.2 \times 10^{2}$ & $0.3 \times 10^{2}$ & $2.4 \times 10^{2}$ & $0.4 \times 10^{2}$ & $3.9 \times 10^{2}$ \\
\hline
\end{tabular}

of physiological bacterial groups. Thionic and ironreducing bacteria were predominant in all drill holes involved in this survey.

\section{References}

Fisher N.K., Kompanichenko V.N. 2007. Thermophilic bacteria in Kuldur hot springs. In: All-Russian Conference "Territorial'nyye Issledovaniya: Tseli, Rezul'taty i Perspektivy [Territorial Studies: Goals, Results and Prospects]", pp. 156-159. (in Russian)

Franke R.B. Bazylinski D.A. 2003. Biologically induced mineralization by bacteria. Reviews in Mineralogy and Geochemistry 54: 95-114. DOI: $10.2113 / 0540095$

Egorov N.S. 1995. Rukovodstvo k prakticheskim zanyatiyam po mikrobiologii [Guide to practical classes in microbiology]. Moscow: MGU. (in Russian)

Kalitina E.G., Kharitonova N.A. Vakh E.A. 2017a. Rasprostraneniye bakteriy razlichnykh ekologo-troficheskikh grupp v podzemnykh termal'nykh vodakh Kul'durskogo mestorozhdeniya (dal'niy vostok Rossii) [The distribution of bacteria of various ecological and trophic groups in the underground thermal waters of the Kuldurskoye deposit (Russian Far East)]. Sovremennyye Problemy Nauki i Obrazovaniya [Contemporary Problems of Science and Education] 5. (in Russian)

Kalitina E.G., Kharitonova N.A., Vakh E.A. 2017b. Microorganisms of various functional groups in the Malkinsky cold carbon dioxide mineral water deposit (Kamchatka, Russia). Mezhdunarodnyy Nauchnyy Zhurnal [International Scientific Journal] 66: 26-29. (in Russian)

Kalitina E.G., Kharitonova N.A., Kuzmina T.V. et al. 2018. Microorganisms in the deposits of cold carbon mineral waters of the Russian Far East and their habitats. IOP Conference Series: Earth and Environmental Science 115. DOI: 10.1088/1755-1315/115/1/012033
Kompanichenko V.N., Poturai V.A. 2015. Variations in the composition of organic matter in the waters of the Kuldursky geothermal field (Russian Far East). Tikhookeanskaya Geologiya [Pacific Geology] 34: 96-107. (in Russian)

Kuznetsov S.I., Dubinina G.A. 1989. Metody izucheniya vodnykh mikroorganizmov [Methods for the study of aquatic microorganisms]. Moscow: Nauka. (in Russian)

Lebedeva E.G., Chelnokov G.A., Bragin I.V. et al. 2019. Microorganisms of various ecological-trophic groups in the saline ground waters of Primorsky Region (distribution, number, participation in accumulation of microelements). E3S Web of Conferences 98. DOI: 10.1051/ e3sconf/20199802006

Lebedeva E.G., Kharitonova N.A. 2019. Physiological and biochemical properties and potential enzymatic activity of heterotrophic bacteria isolated from thermal waters and microbial mats from the Kuldur deposit. Uspekhi Sovremennogo Yestestvoznaniya [Successes in Modern Natural Sciences] 12: 77-82. (in Russian)

Lyamina L.A., Kharitonova N.A., Bragin I.V. et al. 2019. Hydrogeochemical conditions for the formation of nitrogen thermal waters using the example of the Kuldur deposit (Jewish Autonomous Region). In: Problems of Geology and Subsoil Development, pp. 423-425. (in Russian)

Lysak V.V., Zheldakova R.A., Fomina O.V. 2015. Mikrobiologiya. Praktikum: posobiye Microbiology. Practicum: teaching guide]. Minsk: BGU. (in Russian)

Poturai V.A. 2013. Organic matter in groundwater and surface waters of the Kuldurskoye thermal water deposit, Far East of Russia. Vestnik KRAUNTS. Nauki o Zemle [Bulletin of KRAUNTS. Earth Sciences] 21: 169-182. (in Russian)

Romanenko I.V., Karnachuk O.V. 2004. The distribution of sulfate-reducing bacteria in the underground waters of the Paleogene sediments of the Ob-Tomsk interfluve and their possible participation in the mobilization of orthophosphate and manganese. Vestnik Tomskogo Gosudarstvennogo Universiteta [Tomsk State University Bulletin] 30: 134-140. (in Russian)

Vernadsky V.I. 1965. Khimicheskoye stroyeniye biosfery Zemli i ee okruzheniya [The chemical structure of the biosphere of the Earth and its environment]. Moscow: Nauka. (in Russian) 